\title{
Article
}

\section{Calcium And Zinc Deficiency In Preeclamptic Women}

\author{
Selina Akhtar ${ }^{1}$, Shelina Begum², Sultana Ferdousi ${ }^{3}$
}

\begin{abstract}
Background: Pre-eclampsia is the most common medical complication of pregnancy associated with increased maternal and infant mortality and morbidity. Reduced serum calcium and zinc levels are found associated with elevated blood pressure in preeclampsia. Objective: To observe serum calcium and zinc levels in preeclamptic women. Methods: This cross sectional study was carried out in the Department of Physiology, Bangabandhu Sheikh Mujib Medical University, Shahbag, Dhaka between July 2009 to June 2010. In this study, 60 pregnant women of preeclampsia, aged 18-39 years with gestational period more than 20 th weeks were included as the study (group B). For comparison age and gestational period matched 30 normotensive pregnant women control (group A) were also studied. All the subjects were selected from Obstetric and Gynae In and Out patient Department of BSMMU and Dhaka Medical College Hospital. Serum calcium was measured by Colorimetric method and serum zinc was measured by Spectrophotometric method. Data were analysed by independent sample $t$ test and Pearson's correlation coefficient test. Results: Mean serum calcium and zinc levels were significantly $(\mathrm{p}<0.001)$ lower in study group than those of control group. Again, serum calcium and zinc showed significant negative correlation with SBP and DBP in preeclamptic women. Conclusion: This study concludes that serum calcium and zinc deficiency may be one of the risk factor of preeclampsia. Therefore, early detection and supplementation to treat this deficiency may reduce the incidence of preeclampsia.
\end{abstract}

Key words: Calcium, zinc, preeclamptic women.

J Bangladesh Soc Physiol. 2011 December; 6(2): 94-99 For Authors Affiliation, see end of text.

http://www.banglajol.info/index.php/JBSP

\section{Introduction}

$\mathbf{P}$ reeclampsia is a multisystem disorder of unknown etiology affecting approximately 5 to 7 percent of pregnancies, associated with increased maternal and fetal morbidity and mortality ${ }^{1}$.

Preeclampsia stands next to hemorrhage and embolism among pregnancy related cause of death. 790 maternal deaths per 100,000 live births have been reported due to preeclampsia ${ }^{2}$. Its incidence in primigravidae is about $10 \%$ and in multigravidae about $5 \%{ }^{3}$.

Received July 2011; Accepted December 2011
Several groups of researchers reported an association between altered calcium and zinc metabolism in preeclampsia and also focused the possible role of these micronutrient deficiencies in the etiology of the disease. It has been found more common in developing countries due to their low dietary intake of essential minerals and vitamins ${ }^{4}$.

Preeclampsia is caused by multiple factors and elimination of any one factor can reduce the mortality of mothers and infants 5 .

It has been observed that serum calcium level was significantly lower in preeclamptic women 
compared to healthy pregnant women. They mentioned that low serum calcium may cause high blood pressure by stimulating parathyroid hormone and renin release and also by inducing vasoconstriction by increasing its level in vascular smooth muscle ${ }^{4,6,7}$.

Among the essential trace element zinc has an illustrative role in enhancing reproductive health and required for optimal cellular function working with more than 300 different enzymes ${ }^{8,9}$.

It has also been reported that $82 \%$ of the pregnant women worldwide are likely to have inadequate dietary intake of zinc. Physiological alterations of zinc concentration have been found to be related to preeclampsia ${ }^{10,11}$.

Several studies demonstrated an association of zinc deficiency with increased incidence of preeclampsia. Women of low socioeconomic status and women who smoke may have an increased risk of zinc deficiency. Several researchers from different countries observed significantly lower serum zinc levels in preeclamptic women compared to healthy pregnant women $4,8,9,11,12$.

Various studies attempted to explore the link between the changes in levels of serum calcium and zinc in pregnant women and high blood pressure $^{4}$.

In Bangladesh about $16 \%$ of maternal deaths are caused by preeclampsia and Eclampsia ${ }^{13}$. Serum calcium and zinc levels were studied and controversial results were reported in different countries. But most of these are in conclusive and conflicting. Therefore, this study was undertaken to observe the serum calcium and zinc levels in Bangladeshi preeclamptic women in order to find out the possible role of these micronutrients in preeclampsia.

\section{Methods}

This cross sectional study was carried out in the Department of Physiology, Bangabandhu Sheikh Mujib Medical University, Dhaka between July
2009 to June 2010 . The study protocol was approved by the central ethical review committee of this University. For this, 60 diagnosed case of preeclampsia, aged 18-39 years, with gestational period $>20$ th weeks were recruited in the study (group B). For comparison age and gestational period matched 30 normotensive pregnant women were also studied. Following simple random technique, the study and control (group A)subjects were selected from Obstetric and Gynae In and Out patient Department of BSMMU and Dhaka Medical College Hospital. Subjects with history of Diabetes mellitus, renal, cardiovascular, liver disease, chronic hypertension, endocrine disorder, any chronic illness, Hydatidiform mole, Malignancy, Hemophilia were excluded from the study. After selection, the aim and benefit of the study was explained to each subject. When they agreed for participation, a written informed consent was taken. Detailed family and medical history were taken. Thorough clinical examinations of all subjects were done and systolic and diastolic blood pressure were carefully recorded. All information were recorded in a prefixed questionnaire .Then $5 \mathrm{ml}$ of venous blood was collected from ante-cubital vein under aseptic precaution from each subject for biochemical tests. Serum calcium was measured by Colorimetric method and serum zinc level was also determined by Spectrophotometric method. Serum zinc was estimated in the laboratory of the Department of Biochemistry and serum calcium was estimated in the laboratory of the Department of Physiology of BSMMU, Dhaka. Data were expressed as Mean + SD. Data analysis was done by SPSS version12. For statistical significance Independentsamples $t$ test and Pearson's correlation coefficient test were used as applicable.

\section{Results}

In this study, both the groups were matched for age and gestational period, but the mean BMI, SBP and DBP were significantly higher in group $B(p<0.001)$ in comparison to those of group A (Table I).

Mean serum calcium and zinc levels were significantly lower in study group $\mathrm{B}(\mathrm{p}<0.001)$ in comparison to those of control group A (Table II). 
Table 1: Mean \pm SD Age, BMI, Gestational period, SBP and DBP in two groups ( $\mathrm{n}=90)$.

\begin{tabular}{lccc}
\hline Parameters & $\begin{array}{c}\text { Group A } \\
\mathrm{n}=30\end{array}$ & $\begin{array}{c}\text { Group B } \\
\mathrm{n}=60\end{array}$ & $\begin{array}{c}\mathrm{p} \\
\text { value }\end{array}$ \\
\hline Age $($ years $)$ & $25.20 \pm 4.85$ & $25.11 \pm 5.66$ & $0.945^{\mathrm{ns}}$ \\
BMI $\left(\mathrm{kg} / \mathrm{m}^{2}\right)$ & $23.33 \pm 2.14$ & $25.83 \pm 2.43$ & $0.000^{* * *}$ \\
Gestational & $31.53 \pm 3.90$ & $32.35 \pm 3.53$ & $0.321^{\mathrm{ns}}$ \\
period (Weeks) & & & \\
\hline SB $(\mathrm{mm}$ of $\mathrm{Hg})$ & $108 \pm 8.46$ & $155.50 \pm 14.19$ & $0.000^{* * *}$ \\
DBP $(\mathrm{mm}$ of $\mathrm{Hg})$ & $68.66 \pm 8.19$ & $103.83 \pm 10.63$ & $0.000^{* * *}$ \\
\hline
\end{tabular}

$\mathrm{BMI}=$ Body mass index $\mathrm{SBP}=$ Systolic blood pressure $\mathrm{DBP}=$ Diastolic blood pressure $* * *=\mathrm{p}<0.001 \quad \mathrm{~ns}=\mathrm{p}>0.05$

Table II: Mean \pm SD serum calcium and zinc levels in two groups ( $\mathrm{n}=90$ ).

\begin{tabular}{lccc}
\hline Parameters & $\begin{array}{c}\text { Group A } \\
\mathrm{n}=30\end{array}$ & $\begin{array}{c}\text { Group B } \\
\mathrm{n}=60\end{array}$ & $\begin{array}{c}\mathrm{p} \\
\text { value }\end{array}$ \\
\hline Serum calcium $(\mathrm{mg} / \mathrm{dl})$ & $9.08 \pm 0.83$ & $8.19 \pm 0.71$ & $0.000^{* * *}$ \\
Serum zinc $(\mu \mathrm{gm} / \mathrm{l})$ & $1153.33 \pm 67.09$ & $902.50 \pm 157.15$ & $0.000^{* * *}$ \\
\hline
\end{tabular}

Group A = Normotensive pregnant women (control). Group B = Preeclamptic women. $\quad * * *=\mathrm{p}<0.001$

Again, serum calcium and zinc were negatively correlated with SBP and DBP in group A and

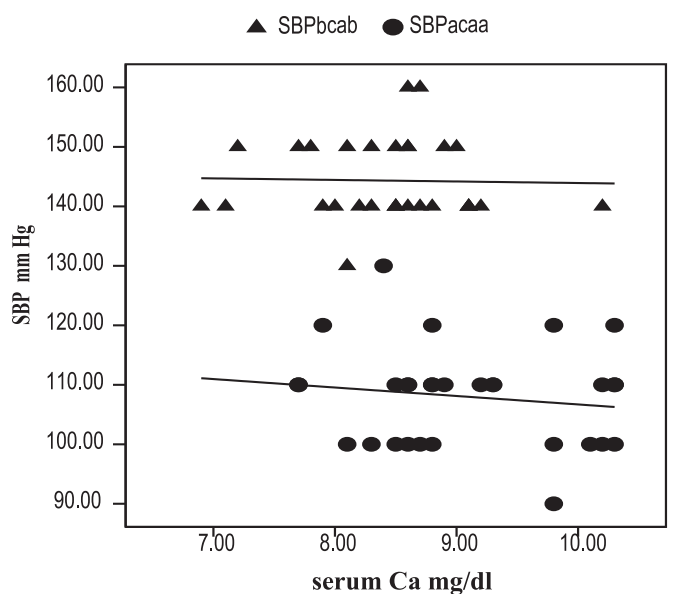

Figure 1: Correlation of SBP with serum Ca levels in both groups $(\mathrm{n}=90)$ group B, but it was significant in preeclamptic women only (Figure 1-4).

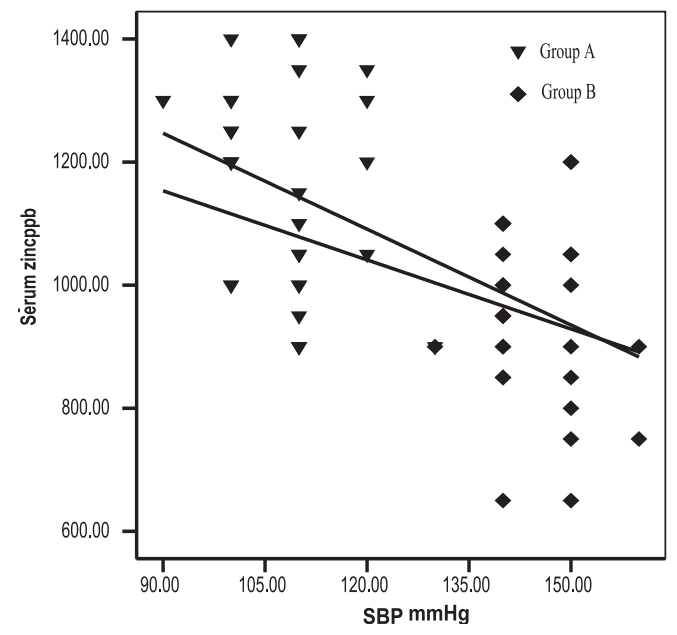

Figure 2: Correlation of SBP with serum $\mathrm{Zn}$ levels in both groups $(\mathrm{n}=90)$ 
Ca \&Zn deficiency in preclampsia

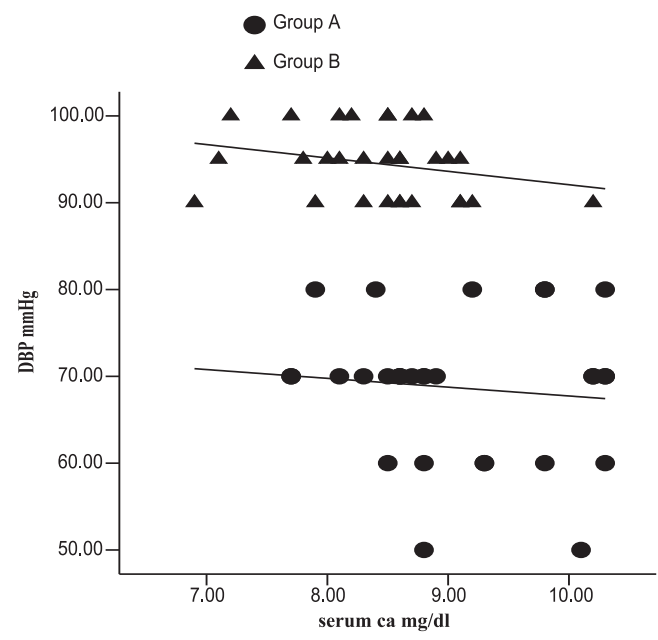

Figure 3: Correlation of DBP with serum Ca levels in both groups $(n=90)$

\section{Discussion}

This study observed significantly lower serum calcium and zinc levels in preeclamptic women than normotensive pregnant women. Similar observations were also reported by other investigators of different countrie $4,6,9,11,14-16$.

Again, in this study in preeclamptic women, the mean value of serum calcium was below the lower limit of normal range but serum zinc were within normal range. On the other hand, the mean values of both these two micronutrients of controls were within normal range.

In the present study significant negative correlation of serum calcium and zinc with SBP and DBP in preeclamptic women suggest strong relationship between deficiency of these trace element and risk of preeclampsia. Research findings from literature suggested that there is a relationship between nutritional status and the onset or progress of the disease and nutritional deficiency might be involved in this disorder. It has been also cited that preeclampsia is more common in poor women. In addition, nutrient can modulate oxidative stress by increasing or decreasing free radicals or antioxidants or by providing substrate for the formation of free radicals ${ }^{17,18}$.

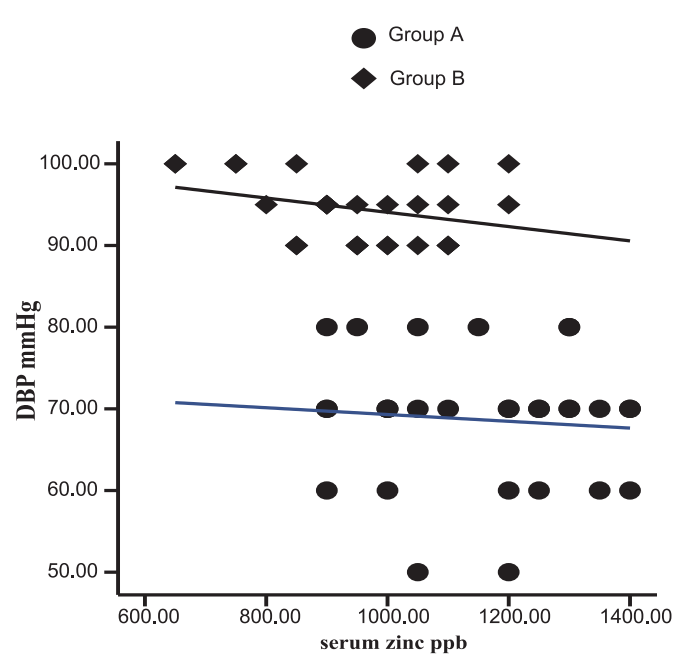

Figure 4: Correlation of DBP with serum $\mathrm{Zn}$ levels in both groups $(\mathrm{n}=90)$

Various investigators suggested that calcium influences smooth muscle cell contractility. Low serum calcium in pregnancy increases release of parathyroid hormone and renin which in turn increases intracellular calcium in vascular smooth muscle. This increased smooth muscle calcium causes vasoconstriction and thereby increased vascular resistance leading to rise in blood pressure in preeclamptic mother $4,6,7,19$.

Increased load of oxidative stress or excessive lipid peroxidation may act as an attributing factor in the pathogenesis of preeclampsia. Zinc is required for the proper functioning of antioxidant enzymes which protect free radicals injury. Deficiency of these elements may withdraw the effect of antioxidant potential of cells leading to increase in blood pressure ${ }^{4,9,11}$.

Various possible explanations were proposed by different investigators to explore the link between nutritional deficiency and preeclampsia. Under increased oxidative stress, ongoing excessive lipid peroxidation, endothelial dysfunction, vasospasm which results from the imbalance of vasodilators and vasoconstrictors in these micronutrient deficient environments may 
progress towards the development of preeclamptic pregnancy $4,6,9,11$

However, it is difficult to comment on all these factors as they were not studied in this study.

In the present study, most of the women are from poor socioeconomic status and obviously their dietary intake of calcium and zinc rich food was inadequate. Though the natural trend of homeostatic mechanism tend to maintain specially calcium and zinc level but still the presence of lower level of serum calcium and zinc in preeclamptic women may indicate the chronicity of micronutrient deficiency which may be a causative factor for the occurrence of this disease in this group of preeclamptic women.

\section{Conclusion}

From this study it may be concluded that deficiency of calcium and zinc in preeclamptic women may be related to their inadequate dietary intake and this micronutrient deficiency may be a risk factor for development of high blood pressure and preeclampsia. Therefore, this study may alert Obstetrician and patients to the harmful effect of these dietary deficiency on obstretic out come. It also emphasizes the need of monitoring serum calcium and zinc during antenatal period and appropriate measures may reduce the incidence of preeclampsia.

\section{Authors Affiliation}

*1. Selina Akhtar, Assistant professor, Department of Physiology, ZH Sikder Women's Medical College, Dhaka. Email: selina.tuba@gmail.com.

2. Shelina Begum, Professor and chairman, Department of Physiology Bangabandhu Sheikh Mujib Medical University ,Shahbag, Dhaka. Email: shelina1985 (a) gmail.com

3. Sultana Ferdousi,Associate Professor, Department of Physiology Bangabandhu Sheikh Mujib Medical University,Shahbag, Dhaka. Email: sferdousiratna (a)gmail.com

*For corrospondance

\section{References}

1. Wagner LK. Diagnosis and management of preeclampsia. Am Fam Physician. 2004; 70 (12):2317- 24.
2. Semenovskaya Erogut M. Pregnancy, preeclampsia. [Internet] 2010, May 27. [Cited 2010, September17]: Abailable from http:// medicine.medscape.com/article/796690-overview.

3. Dutta DC. In: Text Book of Obstetrics. $6^{\text {th }}$ ed. Calcutta: New central book agency (p) ltd; c2006: 46, $52 \mathrm{p}$.

4. Jain S. Sharma P, Kulshreshtha S, Mohan G, Singh $\mathrm{S}$. The role of serum calcium, magnesium, and zinc in preeclampsia. Biol Trace elem Res. 2010; 133(2): $162-70$

5. Bahadoran P, Zendehdel. The relationship between serum zinc and preeclampsia in health centers of Isfahan city in 2007. IJNMR.2010; 15(3): 1-5.

6. Sukonpan K, Phupong V. Serum calcium and serum magnesiumin in normal and preeclamptic pregnancy. Arch Gynecol Obstet.2005; 273: 1216 .

7. Punthumapol C. Kittichotpanich B. Serum calcium, magnesium and uric acid in pre- eclampsia and normal pregnancy. J. Med Assoc Thai. 2008; 91(7): 968-73.

8. Bader AA, Hussain T, Mosawi MA, Otaibi M, Abul H, Khalifa D, Dashti H. Serum zinc and copper concentrations in pregnant women from Kuwait. J. Trace Elem. Exp. Med. 1997; 10: 209-15.

9. Ashraf M, Nasarullah M, Salam A, Khurshid R, Ahmed Z. Maternal serum zinc concentration in gravidae suffering from preeclampsia. A.P.M.C. 2007; 1(1): 24-27.

10. Pathak P, Kapoor SK, Kapil U, Dwivedi SN. Serum magnesium level among pregnant women in a rural community of Haryana state. India. Eur. J. Clin. Nutr. 2003; 57: 1504- 06.

11. Nourmohamm-adi I, Akbaryan A, Fatemi Sh, Meamarzadeh AR Nourmohammadi . Serum zinc concentration in Iranian preeclamptic and normotensive pregnant women. Middle East J. Fam. Med. 2008; 6(4): 30-32.

12. Kocak I, Mir A D, Uston C, Cengiz R. L. Does zinc deficiency have a role in pregnancy induced hypertension? T Klin jmcknl chsi.1999; 9: 18-21.

13. Rashid KM, Rahman M and Hayder S. 2004. Textbook of community medicine and public health, $4^{\text {th }}$ ed.Dhaka:Parash Publishers;2005. 155 p.

14. Malas NO, Shurideh ZM. Does serum calcium in preeclampsia and normal pregnancy differ? Saudi Med J. 2001; 22 (10): 868-71 
Ca \&Zn deficiency in preclampsia

Article

15. Kumru S, Aydin S, Simsek M, Sahin K, Yaman M, Ay G. Comparison of serum copper, zinc, calcium and magnesium levels in preeclamptic and healthy pregnant. Biol Trace elem Res. 2003; 94: 105 12.

16. Akinloye O, Oyewale OJ, Oguntibeju OO. Evaluation of trace elements in pregnant women with preeclampsia. Afr. J. Biotechnol.2010; 9(32):5196-02.
17. Vasiljevic N, Vasiljevic M, Plecas D. The role of nutritional factors in preeclampsia and eclampsia. Srp Arh Celok Lek. 1996; 124(5-6): 156-59.

18. Roberts JM, Balk JL, Bodner LM, Belizan JM, Berge E, Martinez A. Nutrient involvement in preeclampsia.2003; J Nutr; 133(55): 1684-92.

19. Ritchie LD, King JC. Dietary calcium and pregnancy induced hypertension: is there a relation? Am J Clin Nutr. 2000; 71(50:1371-74. 